\section{Improvement in Growth, Yield, and Fruit Quality of Three Red Sweet Pepper Cultivars by Foliar Application of Humic and Salicylic Acids}

\author{
Abdullah Ibrahim ${ }^{1}$, Hesham Abdel-Razzak ${ }^{1,2}$, \\ Mahmoud Wahb-Allah ${ }^{1,2}$, Mekhled Alenazi ${ }^{1}$, \\ Abdullah Alsadon ${ }^{1}$, and Yaser Hassan Dewir ${ }^{1,3,4}$
}

\begin{abstract}
Additional Index words. Capsicum annumm, flesh thickness, large fruit size, nutritional value, vitamin $C$

SUMMARY. The present study reports on the effect of humic and salicylic acids on the growth, yield, and fruit quality of three red sweet pepper (Capsicum annuиm) cultivars: Barbero, Ferrari, and Imperio. The plants were grown in a greenhouse and the leaves were treated with humic or salicylic acids at $0,0.5,1.0$, and $1.5 \mathrm{~g} \cdot \mathrm{L}^{-1}$ at 20,40 , and 60 days after transplanting. Foliar application of humic or salicylic acids significantly increased vegetative growth, fruit yield, and quality of the three cultivars as compared with the control plants. However, salicylic acid treatment proved more effective than humic acid treatment. Red sweet pepper plants of all three cultivars sprayed with $1.5 \mathrm{~g} \cdot \mathrm{L}^{-1}$ salicylic acid showed the greatest vegetative growth; fruit yield components, such as fruit number, diameter, and fresh and dry weights; and fruit quality traits, such as vitamin $\mathrm{C}$ content, total soluble solid content, titratable acidity, and total sugar content, than the plants in all other treatments. There were significant differences $(P \leq 0.05)$ among cultivars in response to humic and salicylic acid foliar application; 'Ferrari' showed significantly higher yield and productivity than 'Barbero' or 'Imperio'. 'Ferrari' plants sprayed with $1.5 \mathrm{~g} \cdot \mathrm{L}^{-1}$ salicylic acid showed the highest fruit weight $(202.41 \mathrm{~g})$ and flesh thickness $(68 \mathrm{~mm})$, both of which are preferred by consumers, and therefore, have increased market value. This treatment also increased total yield by $27.7 \%$ (16.03 $\left.\mathrm{t} \cdot \mathrm{ha}^{-1}\right), \mathbf{1 5 . 9 \%}\left(12.38 \mathrm{t} \cdot \mathrm{ha}^{-1}\right)$, and $17.9 \%\left(11.88 \mathrm{t} \cdot \mathrm{ha}^{-1}\right)$ in 'Barbero', 'Ferrari', and 'Imperio', respectively. Therefore, salicylic acid foliar application is recommended for enhancing fruit yield and quality of greenhouse-grown red sweet pepper.
\end{abstract}

$\mathrm{T}$ he genus Capsicum is composed of 40 species (The Plant List, 2019). This genus includes important vegetable crop species throughout the world and many different hot and sweet cultivars, which differ vastly in shape,

Received for publication 26 Dec. 2018. Accepted for publication 22 Jan. 2019.

Published online 19 March 2019

The authors extend their appreciation to the Deanship of Scientific Research at King Saud University for funding this work through Research Group No. RGP-1438-011, and the Researchers Support \& Services Unit for their technical support.

${ }^{1}$ Plant Production Department, P.O. Box 2460, College of Food and Agricultural Sciences, King Saud University, Riyadh 11451, Saudi Arabia

${ }^{2}$ Vegetable Crops Department, Faculty of Agriculture, Alexandria University, Alexandria 21545, Egypt ${ }^{3}$ Department of Horticulture, Faculty of Agriculture, Kafrelsheikh University, Kafr El-Sheikh 33516, Egypt

${ }^{4}$ Corresponding author. E-mail: ydewir@hotmail.com or ydewir@ksu.edu.sa.

This is an open access article distributed under the CC BY-NC-ND license (https://creativecommons.org/ licenses/by-nc-nd/4.0/).

https://doi.org/10.21273/HORTTECH04263-18 size, and color, among other characteristics. Red sweet pepper fruit contain high health-promoting bioactive compounds, like phenolics, carotenoids, and antioxidants, such as $\beta$-carotene which serves as provitamin $\mathrm{A}$ (Arimboor et al., 2015; Chávez-Mendoza et al., 2015; Emmanuel-Ikpeme et al., 2014;
Jamiołkowska et al., 2016). Consumers judge the quality of sweet pepper fruit by their weight, pericarp thickness, color, and nutritional value, generally preferring fruit that are heavier, thicker, more colorful at full ripeness, and more nutritious (Buczkowska et al., 2014; Jadczak et al., 2010; Jamiołkowska et al., 2016). The use of natural biostimulants (Mahmood et al., 2017; Paradikovic et al., 2011), foliar feeding (Haytova, 2013), and plant growth regulators (Pérez-Jiménez et al., 2015) have been recently introduced to improve the quality of vegetable products. Foliar fertilization is a common crop-management strategy to maximize yield and fruit quality (Haytova, 2013) and help plants compensate for low soil fertility, nutrient uptake limitations, and nutrient fixation (Dada and Ogunsesu, 2016). Common organic-mineral fertilizers used in plant fertilization are humic substances, which contain humic acid (Manas et al., 2014).

Humic substances are the components of humus and as such are high molecular weight compounds that together form the brown to black hydrophilic, molecularly flexible, polyelectrolytes called humus. Humic acids comprise a mixture of weak aliphatic (carbon chains) and aromatic (carbon rings) organic acids, which are not soluble in water under acid conditions but are soluble in water under alkaline conditions. These substances play a vital role in soil fertility and plant nutrition (Ghabbour and Davies, 2001). Humic acid has been applied both to the soil and as foliar sprays (Manas et al., 2014). Previous studies reported that plant fertilization with humic acid promotes plant growth, development,

\begin{tabular}{|c|c|c|c|}
\hline $\begin{array}{l}\text { Units } \\
\text { To convert U.S. to SI, } \\
\text { multiply by }\end{array}$ & U.S. unit & SI unit & $\begin{array}{l}\text { To convert SI to U.S., } \\
\text { multiply by }\end{array}$ \\
\hline 0.3048 & $\mathrm{ft}$ & $\mathrm{m}$ & 3.2808 \\
\hline 0.0929 & $\mathrm{ft}^{2}$ & $\mathrm{~m}^{2}$ & 10.7639 \\
\hline 0.0283 & $\mathrm{ft}^{3}$ & $\mathrm{~m}^{3}$ & 35.3147 \\
\hline 0.0700 & $\mathrm{ft}^{3} /$ acre & $\mathrm{m}^{3} \cdot \mathrm{ha}^{-1}$ & 14.2913 \\
\hline 3.7854 & gal & L & 0.2642 \\
\hline 2.54 & inch(es) & $\mathrm{cm}$ & 0.3937 \\
\hline 25.4 & inch(es) & $\mathrm{mm}$ & 0.0394 \\
\hline 6.4516 & inch $^{2}$ & $\mathrm{~cm}^{2}$ & 0.1550 \\
\hline 0.4536 & $\mathrm{lb}$ & $\mathrm{kg}$ & 2.2046 \\
\hline 1.1209 & $\mathrm{lb} / \mathrm{acre}$ & $\mathrm{kg} \cdot \mathrm{ha}^{-1}$ & 0.8922 \\
\hline 1 & $\mathrm{meq} / \mathrm{L}$ & $\mathrm{mmol} \cdot \mathrm{L}^{-1}$ & 1 \\
\hline 1 & $\mathrm{mmho} / \mathrm{cm}$ & $\mathrm{d} S \cdot \mathrm{m}^{-1}$ & 1 \\
\hline 28.3495 & $\mathrm{oz}$ & $\mathrm{g}$ & 0.0353 \\
\hline 0.001 & ppm & $\mathrm{g} \cdot \mathrm{L}^{-1}$ & 1000 \\
\hline 0.1 & $\mathrm{ppm}$ & $\mathrm{mg} / 100 \mathrm{~g}$ & 10 \\
\hline 2.2417 & ton(s)/acre & $\mathrm{t} \cdot \mathrm{ha} \mathrm{a}^{-1}$ & 0.4461 \\
\hline$\left({ }^{\circ} \mathrm{F}-32\right) \div 1.8$ & ${ }^{\circ} \mathrm{F}$ & ${ }^{\circ} \mathrm{C}$ & $\left({ }^{\circ} \mathrm{C} \times 1.8\right)+32$ \\
\hline
\end{tabular}


production, and fruit quality of vegetable crops (reviewed by Haytova, 2013). Foliar spraying with humic acid promoted growth, yield, and fruit quality of 'Demre sivrisi' sweet pepper (Karakurt et al., 2009) by increasing nutrient uptake and supplying mineral nutrients (Atiyeh et al., 2002; Unlu et al., 2011).

Salicylic acid is a natural growth regulator of vascular plants that influences several physiological and metabolic processes (Jayakannan et al., 2015: Rivas-San Vicente and Plasencia, 2011), such as photosynthesis, transpiration, ion uptake, and transportation (Sahu, 2013). Foliar application of salicylic acid may increase the yield of vegetable species by reducing stress-induced growth inhibition (Khan et al., 2015). In general, humic and salicylic acids positively affect plant growth and development by acting as an organic-mineral fertilizer and a phytohormone, respectively. However, the responses of vegetable species and cultivars to either humic or salicylic acid application can differ significantly. Therefore, it is important to find the best treatment concentration in each case (Aghaeifard et al., 2016). Few studies have investigated the effect of salicylic acid on the qualitative and quantitative traits of sweet pepper plants. Salicylic acid was applied as a foliar spray on greenhousegrown 'Twingo' sweet pepper (Elwan and El-Hamahmy, 2009), field-grown 'California Wonder' sweet pepper (Abou El-Yazied, 2011), and 'Cadia' sweet pepper [as a presowing treatment (Hanieh et al., 2013)]. In the present study, attempt has been made to assess the influence of foliar application of different humic and salicylic acid concentrations on the growth, productivity, and fruit quality of three red sweet pepper cultivars growing under greenhouse conditions.

\section{Materials and methods}

Plant material and Seed GERMINATION. Seeds of three hybrid red sweet pepper cultivars of indeterminate growth habit (Barbero, Ferrari, and Imperio) were purchased from Enza Zaden (Voorst, The Netherlands). Seeds of the three cultivars were germinated in Styrofoam seedling trays under a controlled environment $\left[25 / 18 \pm 3{ }^{\circ} \mathrm{C}\right.$ (day/ night) air temperatures and $75 \% \pm 2 \%$ relative humidity $(\mathrm{RH})]$ for 6 weeks in greenhouse at the Agricultural Research and Experimental Station in Dirab, Riyadh, Saudi Arabia (lat. $46^{\circ} 44^{\prime} \mathrm{E}$, long. $24^{\circ} 39^{\prime} \mathrm{N}$ ).

SEEDLING GROWTH IN THE CONTROLLED - EN VIRON MENT GREENHOUSE. Healthy and uniformly sized seedlings (three to four true leaf stage) were transplanted into greenhouse $(65 \times 10 \times 3.5 \mathrm{~m})$ ground soil $43 \mathrm{~d}$ after seed sowing. Soil analysis was carried out according to Chapman and Pratt (1961) and the main characteristics of soil are presented in Table 1. The hydrometer method was used to determine of particle size analyses (Bouyoucos, 1951). The $\mathrm{pH}$ and electrical conductivity of the soil were measured using a $\mathrm{pH}$ meter (Orion star A211; Thermo Fisher Scientific, Waltham, MA) and a conductivity meter (Orion star A212; Thermo Fisher Scientific), respectively. Potassium $\left(\mathrm{K}^{+}\right)$and sodium $\left(\mathrm{Na}^{+}\right)$were measured using a microprocessor flame photometer (model 1382; ESICO, Haryana, India). EDTA-disodium, silver nitrate, hydrochloric acid solutions were respectively used for determination of calcium $\left(\mathrm{Ca}^{2+}\right)$, magnesium $\left(\mathrm{Mg}^{2+}\right)$, chlorine $\left(\mathrm{Cl}^{-}\right)$, and bicarbonate $\left(\mathrm{HCO}_{3}{ }^{-1}\right)$ by titration, and sulfate $\left(\mathrm{SO}_{4}{ }^{-2}\right)$ was determined using a digital turbidity meter (DRT 100B; HF Scientific, Ft. Meyers, FL). Air temperature and $\mathrm{RH}$ were maintained at 26/ $19 \pm 1{ }^{\circ} \mathrm{C}$ (day/night), and 75\% $\pm 2 \%$ $\mathrm{RH}$, respectively. Irrigation and fertilization were started $7 \mathrm{~d}$ after transplanting and a drip irrigation system was used with dripper spacing of $0.5 \mathrm{~m}$ and a $4.0 \mathrm{~L} \cdot \mathrm{h}^{-1}$ discharge rate per emitter. The total period of the irrigation was $173 \mathrm{~d}$ and the amount of total irrigation applied during plant growth period was $6000 \mathrm{~m}^{3} \cdot \mathrm{ha}^{-1}$. Irrigation was daily applied at three growth stages: First stage: Vegetative [7 to $45 \mathrm{~d}$ after transplanting $\left(853 \mathrm{~m}^{3}\right)$ ], second stage: Flowering to fruit set [46 to $\left.90 \mathrm{~d}\left(1374 \mathrm{~m}^{3}\right)\right]$, and third stage: Fruit development to harvest $\left[90\right.$ to $\left.180 \mathrm{~d}\left(3873 \mathrm{~m}^{3}\right)\right]$. Irrigation scheduling was based on crop weekly evapotranspiration following pan evaporation according to Allen et al. (1998) and Harmanto et al. (2005). Fertilization was applied as recommended in commercial sweet pepper production according to Maynard and Hochmuth (2007). The total amount of nitrogen $(\mathrm{N})$, phosphorous $(\mathrm{P})$, and potassium $(\mathrm{K})$ were applied at a rate of $\left(\mathrm{kg} \cdot \mathrm{ha}^{-1}\right) 245 \mathrm{~N}$, $122 \mathrm{P}$, and $664 \mathrm{~K}$ (Alsadon et al., 2013). NPK fertilization $\left(\mathrm{NH}_{4} \mathrm{NO}_{3}\right.$, $\mathrm{H}_{3} \mathrm{PO}_{4}$, and $\mathrm{KSO}_{4}$ ) was applied by fertigation for each growth stage as follows $\left(\mathrm{kg} \cdot \mathrm{ha}^{-1}\right)$ : vegetative stage (66N-8P-54K), flowering stage $(82 \mathrm{~N}-46 \mathrm{P}-186 \mathrm{~K})$, and fruit development stage $(97 \mathrm{~N}-58 \mathrm{P}-424 \mathrm{~K})$. To encourage initial vegetative growth, the first crown flower and secondorder flowers were pulled from the plants of the three cultivars in all treatments. Lateral shoots and flowers, just above the cotyledonary node, were also removed. The training system was applied to form a plant structure of two main branches (Alsadon et al., 2013) to form a "V" trellising canopy system (Jovicich et al., 2007). When pruning a main branch, only the flower on the branch node and its nearby leaf were left. After $21 \mathrm{~d}$ after transplanting, at 2 -week intervals, all side branches were removed on the main branches to enhance upward growth and fruiting on trained main branches only. In addition, older leaves were removed from the lower parts of stems to allow for more air circulation and light within the canopy. The plants were supported using silk wires at a height

Table 1. Physical and chemical properties of the experimental greenhouse soil used for growing 'Barbero', 'Ferrari', and 'Imperio' sweet pepper.

\begin{tabular}{|c|c|c|c|c|c|c|c|c|c|c|c|}
\hline \multicolumn{3}{|c|}{ Soil texture } & \multirow[b]{2}{*}{$\mathrm{pH}$} & \multirow[b]{2}{*}{$\mathrm{EC}\left(\mathrm{dS} \cdot \mathrm{m}^{-1}\right)^{\mathrm{z}}$} & \multicolumn{4}{|c|}{ Cations $(\mathrm{meq} / \mathrm{L})^{\mathrm{y}}$} & \multicolumn{3}{|c|}{ Anions $(\mathrm{meq} / \mathrm{L})^{\mathrm{x}}$} \\
\hline Clay (\%) & Silt (\%) & Sand (\%) & & & $\overline{\mathbf{C a}^{++}}$ & $\mathrm{Mg}^{++}$ & $\mathrm{Na}^{+}$ & $\mathbf{K}^{+}$ & $\overline{\mathrm{Cl}^{-}}$ & $\mathrm{HCO3}^{-}$ & $\mathrm{SO}^{--}$ \\
\hline 6.88 & 3.7 & 89.45 & 8.18 & 1.96 & 12.71 & 3.93 & 2.17 & 0.96 & 6.86 & 4.16 & 8.7 \\
\hline
\end{tabular}

${ }^{\mathrm{z}}$ Electrical conductivity, $\mathrm{l} \mathrm{dS} \cdot \mathrm{m}^{-1}=1 \mathrm{mmho} / \mathrm{cm}$

${ }^{\mathrm{y}} \mathrm{Ca}^{++}=$calcium, $\mathrm{Mg}^{++}=$magnesium, $\mathrm{Na}^{+}=$sodium, $\mathrm{K}^{+}=$potassium, $1 \mathrm{meq} / \mathrm{L}=1 \mathrm{mmol} \cdot \mathrm{L}^{-1}$.

${ }^{\mathrm{x}} \mathrm{Cl}^{-}=$chlorine, $\mathrm{HCO}_{3}{ }^{-}=$bicarbonate, $\mathrm{SO}_{4}{ }^{--}=$sulfate. 
of $2.5 \mathrm{~m}$ above the ground. There were no applications of pesticides, and the weeds were removed manually by hand pulling. The harvest started $85 \mathrm{~d}$ after transplanting and the crop was harvested 12 times.

Foliar APPLICATION OF HUMIC AND SALICYLIC ACIDS. Humic acid [ $80 \%$ total humic extract, $76 \%$ humic acid, $4 \%$ fulvic acid, with $12 \%$ potash $\left(\mathrm{K}_{2} \mathrm{O}\right)$ (Solum H80; Sustainable Agro Solutions, Almacelles-Lleida, Spain)] and salicylic acid concentrations of 0 , $0.5,1.0$, and $1.5 \mathrm{~g} \cdot \mathrm{L}^{-1}$ were sprayed on the leaves at 20,40 , and $60 \mathrm{~d}$ after transplanting. Nontreated plants served as controls. Salicylic acid was dissolved in a few drops of dimethyl sulfoxide $\left\{\right.$ DMSO $\left.\left[\left(\mathrm{CH}_{3}\right)_{2} \mathrm{SO}\right]\right\}$ and then diluted to the final volume using distilled water (Elwan and El-Hamahmy, 2009). To attain maximum absorption of humic and salicylic acids, plant leaves were sprayed until dripping during morning hours (Karakurt et al., 2009). All sprays were done using a 10-L hand-held sprayer (STAR 10; Pompa A Pressicne, Vicenza, Italy). To prevent spray treatments of different concentrations from interfering with one another, a distance of $1 \mathrm{~m}$ was left between the spot of two applications.

Measurements OF PLANT GROWTH AND FRUIT PHYSICAL TRAITS. Plant growth parameters, including leaf area, stem length, and fresh weight, were recorded from 10 plants for each treatment $80 \mathrm{~d}$ after transplanting. The leaf area was measured using a portable area meter (LI3000A; LI-COR, Lincoln, NE). Dry weight was determined after oven drying at $70{ }^{\circ} \mathrm{C}$ for $48 \mathrm{~h}$. For fruit physical traits, 10 fruit obtained from five plants were randomly selected from each treatment at the fifth harvest. Five fruit from each treatment were used to measure average fruit fresh weight (grams), fruit dimensions [length and diameter (centimeters)], and fruit flesh thickness (centimeters) using a Vernier caliper. The other five fruit were cut into slices, and a random sample (50 g) was dried at $70{ }^{\circ} \mathrm{C}$ in an air-drying oven for $48 \mathrm{~h}$. To determine fruit yield grades, fruit yield and the components of fruit yield, harvested fruit (at the full-red color stage) were weighed and separated into three grades, based on the fruit diameter scale used for greenhouse-grown sweet peppers (Jovicich et al., 2007), as follows: small $(<65 \mathrm{~mm})$, medium $(65-75 \mathrm{~mm})$, and large $(>75 \mathrm{~mm})$. In addition, total fruit yield (tonnes per hectare) and its components (i.e., number of fruit per plant and average fruit weight) were recorded after each harvest.

Measurements OF Fruit NUTRITIONAL QUALITY TRAITS. Five fruit were randomly collected from each treatment, homogenized in a kitchen blender, and used for the analytical determination of vitamin $\mathrm{C}$ content, total soluble solid content, titratable acidity, and total sugar content. The content of vitamin $\mathrm{C}$ was measured using the classic titration method with 2, 6-dichlorophenol indophenol solution and was expressed in milligrams of ascorbic acid per 100 $\mathrm{g}$ fresh weight [Association of Official Analytical Chemists (AOAC), 2000]. Total soluble solids were determined by a portable digital refractometer (PR-101 Palette Series; Atago Co., Tokyo, Japan), as described by César de O Charlo et al. (2011). Titratable acidity was determined by titration of the fruit homogenate $(5.0 \mathrm{~g})$ with $0.1 \mathrm{~m}$ sodium hydroxide $(\mathrm{NaOH})$ at $\mathrm{pH} 8.1$, using citric acid as a control. Percentage of total sugars was determined using AOAC (2000) standard procedures.

EXPERIMENTAL DESIGN AND STATISTICAL ANALYSIS. The treatments were adopted in a factorial system in randomized complete block design, with three replications. Each treatment was established in three rows (replicates) spaced $1.0 \mathrm{~m}$ apart, with an intrarow spacing of $0.40 \mathrm{~m}$. Each replicate had an area of $8 \mathrm{~m}^{2}(1 \times 8 \mathrm{~m})$ and contained 16 plants. The experiment was conducted on 9 Sept. 2012 and repeated on 2 Sept. 2013. The mean values of the two experiments for two growing seasons are presented in this report. Statistical analysis was conducted using SAS statistical software (version 8.1; SAS Institute, Cary, NC). Mean separation was carried out using Tukey's multiple range test, with the significance threshold set at $P \leq 0.05$.

\section{Results and discussion}

EFFECT OF HUMIC AND SALICYLIC ACIDS ON VEgETATIVE GROWTH TRAITs. Foliar application of humic and salicylic acids significantly $(P \leq$
0.05 ) increased vegetative growth of the three red sweet pepper cultivars, as compared with the control treatment (Table 2). All growth parameters were significantly $(P \leq 0.05)$ influenced by cultivar, foliar application, year, and the interaction for cultivars with foliar treatments. However, dry weight was not significantly influenced by year. Leaf area and fresh weight were significantly $(P \leq 0.05)$ influenced by the interaction for cultivar and year (Table 2). Salicylic acid at $1.5 \mathrm{~g} \cdot \mathrm{L}^{-1}$ resulted in the highest mean leaf area, stem length, and fresh and dry weight in all cultivars, as compared with that in the other treatments. Control plants exhibited the poorest vegetative growth. 'Ferrari' plants exhibited more vigorous vegetative growth represented by higher plant leaf area and stem length than either 'Barbero' or 'Imperio' plants (Table 2). These results are attributed to the genotypic differences among the three sweet pepper cultivars. Plant biomass has been shown to correlate with an increase of photo-assimilates, which determine the extent of dry weight distribution to sink organs (Dada and Ogunsesu, 2016). Exogenous application of salicylic acid may influence a range of plant processes, including stomatal closure, ion uptake and transport (Gunes et al., 2005), membrane permeability (Barkosky and Einhellig 1993), and photosynthetic and growth rates (Khan et al., 2003). In 'California Wonder' sweet pepper, salicylic acid has been reported to increase vegetative growth, photosynthetic pigments, mineral content, and endogenous auxin and cytokinin levels, while decreasing abscisic acid level (Abou El-Yazied, 2011).

Our results also indicated that red sweet pepper plants treated with humic acid exhibited significant increases in all vegetative growth traits as compared with the controls, but to a lesser extent than that achieved in the salicylic acid treatments. Humic acid has been reported to increase vegetative growth in several crops including potato [Solanum tuberosum (Alenazi et al., 2016)], snap bean [Phaseolus vulgaris (Hanafy Ahmed et al., 2010)], and 'Target NFl' tomato [Solanum lycopersicum (Yildirim, 2007)]. The observed increase in growth of sweet pepper plants treated with humic acid could be due to its 
Table 2. Effect of humic and salicylic acids concentrations on growth of 'Barbero', 'Ferrari', and 'Imperio' sweet pepper.

\begin{tabular}{|c|c|c|c|c|c|c|}
\hline \multirow[b]{2}{*}{ Cultivar } & \multicolumn{2}{|c|}{ Foliar treatment $\left(\mathrm{g} \cdot \mathrm{L}^{-1}\right)^{\mathrm{z}}$} & \multirow{2}{*}{$\begin{array}{c}\text { Leaf area } \\
\left(\mathrm{cm}^{2} / \text { plant }\right)^{\mathrm{z}}\end{array}$} & \multirow{2}{*}{$\begin{array}{l}\text { Stem length } \\
(\mathrm{cm} / \text { plant })^{\mathrm{z}}\end{array}$} & \multirow{2}{*}{$\begin{array}{c}\text { Fresh wt } \\
(\mathrm{g} / \text { plant })^{\mathrm{z}}\end{array}$} & \multirow{2}{*}{$\begin{array}{c}\text { Dry wt } \\
\text { (g/plant) }\end{array}$} \\
\hline & Humic acid & Salicylic acid & & & & \\
\hline \multirow[t]{4}{*}{ Barbero } & 0 & 0 & $4,620 \mathrm{k}^{\mathrm{y}}$ & $86 \mathrm{~m}$ & $462.7 \mathrm{~m}$ & $34.0 \mathrm{~m}$ \\
\hline & 1.0 & 0 & $4,720 \mathrm{j}$ & $96 \mathrm{k}$ & $478.6 \mathrm{k}$ & $38.3 \mathrm{k}$ \\
\hline & 1.5 & 0 & $4,746 \mathrm{ij}$ & $105 \mathrm{j}$ & $485.5 \mathrm{j}$ & $41.0 \mathrm{i}$ \\
\hline & 0 & 0.5 & $4,701 \mathrm{j}$ & $97 \mathrm{k}$ & $477.5 \mathrm{kl}$ & $38.0 \mathrm{k}$ \\
\hline \multirow[t]{5}{*}{ Ferrari } & 0 & 0 & $6,695 \mathrm{~cd}$ & $118 \mathrm{e}$ & $554.9 \mathrm{e}$ & $45.0 \mathrm{f}$ \\
\hline & 0.5 & 0 & $6,759 \mathrm{bc}$ & $126 \mathrm{~d}$ & $568.3 \mathrm{~d}$ & $47.7 \mathrm{e}$ \\
\hline & 1.0 & 0 & $6,776 \mathrm{~b}$ & $133 \mathrm{~b}$ & $572.2 \mathrm{~cd}$ & $50.0 \mathrm{~d}$ \\
\hline & 1.5 & 0 & $6,811 \mathrm{ab}$ & $135 \mathrm{a}$ & $577.1 \mathrm{bc}$ & $54.0 \mathrm{c}$ \\
\hline & 0 & 0.5 & $6,785 \mathrm{~b}$ & $130 \mathrm{c}$ & $572.8 \mathrm{~cd}$ & $55.3 \mathrm{~b}$ \\
\hline & 1.0 & 0 & $6,508 \mathrm{ef}$ & $109 \mathrm{gh}$ & 529.6 & $44.0 \mathrm{~g}$ \\
\hline & 1.5 & 0 & $6,671 \mathrm{~d}$ & $115 \mathrm{f}$ & $539.1 \mathrm{f}$ & $46.0 \mathrm{f}$ \\
\hline & 0 & 0.5 & $6,482 \mathrm{fg}$ & $111 \mathrm{~g}$ & $533.6 \mathrm{fg}$ & $43.0 \mathrm{~h}$ \\
\hline & 0 & 1.0 & $6,573 \mathrm{e}$ & $115 \mathrm{f}$ & $539.8 \mathrm{f}$ & $46.0 \mathrm{f}$ \\
\hline & 0 & 1.5 & $6,750 \mathrm{bc}$ & $119 \mathrm{e}$ & 550.9 e & $48.3 \mathrm{e}$ \\
\hline & & & Significance & & & \\
\hline \multicolumn{3}{|l|}{ Cultivar } & * & * & * & * \\
\hline \multicolumn{3}{|c|}{ Foliar treatment } & * & * & * & * \\
\hline \multicolumn{3}{|l|}{ Year } & * & * & * & NS \\
\hline \multicolumn{3}{|c|}{ Cultivar $\times$ foliar treatment } & * & * & * & * \\
\hline \multicolumn{3}{|c|}{ Cultivar $\times$ year } & * & NS & * & NS \\
\hline
\end{tabular}

${ }^{\mathrm{z}} \mathrm{l} \mathrm{g} \cdot \mathrm{L}^{-1}=1000 \mathrm{ppm}, 1 \mathrm{~cm}^{2}=0.1550 \mathrm{inch}^{2}, 1 \mathrm{~cm}=0.3937 \mathrm{inch}, 1 \mathrm{~g}=0.0353 \mathrm{oz}$.

'Values followed by the same letter in the same column are not significantly different at $P \leq 0.05$ level, according to Tukey's range test.

Ns, *Nonsignificant or significant at $P \leq 0.05$, respectively.

beneficial influence on soil physicochemical and biological properties (Asri et al., 2015; Brannon and Sommers, 1985). Furthermore, this increase could be attributed to the nutrients supplied by the humic acid. Adani et al. (1998) and Asri et al. (2015) reported that the stimulating effect of humic acid on tomato plant growth has been attributed to the enhanced uptake of major nutrients (i.e., $\mathrm{N}, \mathrm{P}, \mathrm{Fe}$, and $\mathrm{Cu}$ ), whereas the enhanced availability of micro- and macronutrients may be responsible for increased fresh and dry leaf weight (Dursun et al., 2002; Eshghi and Garazhian, 2015; Salman et al., 2005).

EFFECT OF HUMIC AND SALICYLIC ACID CONCENTRATIONS ON FRUIT YIELD TRAITS. Yield traits of the three cultivars of red sweet pepper were significantly $(P \leq 0.05)$ enhanced by foliar application of humic and salicylic acids. The percentage of large fruit was not significantly influenced by year, whereas the percentage of small fruit was not significantly influenced by the interaction for cultivar and year (Table 3 ). The interaction between year with foliar treatments and their concentrations showed no significant effect for all yield traits (Table 3). Salicylic acid treatments were, again, more effective than humic acid treatments. Application of $1.5 \mathrm{~g} \cdot \mathrm{L}^{-1}$ salicylic acid produced the highest number of fruit, at 16.3 , 17.8 , and 16.7 fruit for 'Barbero', 'Ferrari', and 'Imperio', respectively, as compared with their control treatments $(14.5,16.5$, and 15.2, for the three cultivars, respectively). Salicylic acid increased the percentage of large fruit, whereas it reduced the percentage of small and medium fruit. At 1.5 $\mathrm{g} \cdot \mathrm{L}^{-1}$ salicylic acid application, 'Ferrari' had the highest percentage of large fruit $(83.5 \%)$, yield per plant $(3.59 \mathrm{~kg})$, and total yield $(89.89$ $\left.\mathrm{t} \cdot \mathrm{ha}^{-1}\right)$, whereas 'Barbero' had the lowest percentage of large fruit, yield per plant, and total yield (56.8\%, 2.94 $\mathrm{kg}$, and $73.7 \mathrm{t} \cdot \mathrm{ha}^{-1}$, respectively). The increase in total yield of 'Barbero', 'Ferrari', and 'Imperio' is attributed to the increase in number of fruit per plant and the increased percentage of the larger fruit grades. Similar findings were also reported in 'Hybrid Ranco-365' chili pepper [C. annuum (Fathima and Denesh, 2013)].

Generally, the foliar spraying method plays a vital role in improving the growth and yield of vegetable crops by increasing plant nutrient uptake and efficiency (Haytova, 2013; Souri et al., 2017). In this study, the highest yields obtained using high concentrations of humic acid could be attributed to the latter's influence on essential nutrients, which improved plant growth and fruit yield (Adani et al., 1998; Alenazi et al., 2016; Dursun et al., 2002). Furthermore, humic acid acts as 
Table 3. Effect of humic and salicylic acid concentrations on yield traits of 'Barbero', 'Ferrari', and 'Imperio' sweet pepper.

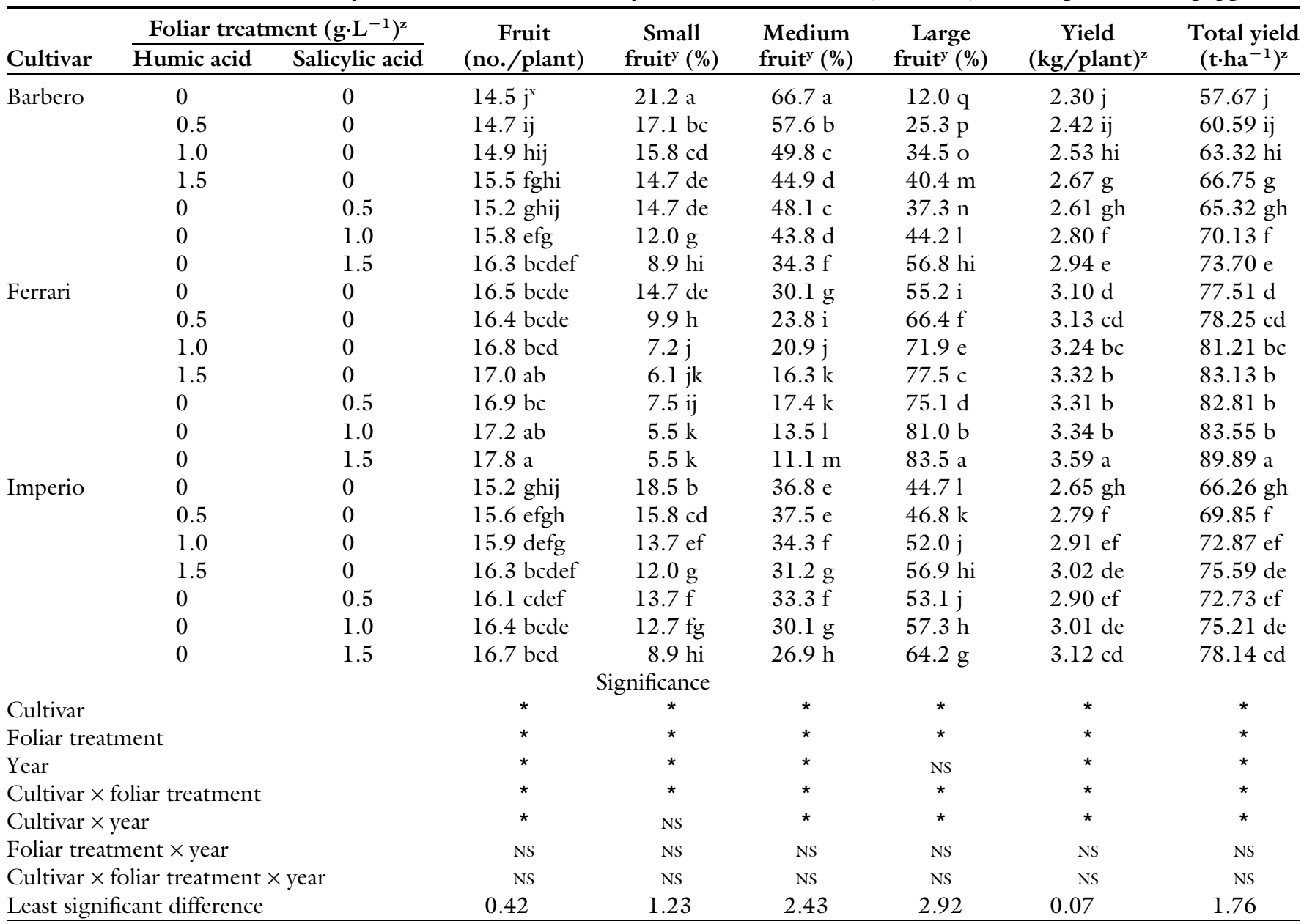

${ }^{\mathrm{z}} \mathrm{l} \mathrm{g} \cdot \mathrm{L}^{-1}=1000 \mathrm{ppm}, \mathrm{l} \mathrm{kg}=2.2046 \mathrm{lb}, \mathrm{l} \mathrm{t} \cdot \mathrm{ha}^{-1}=0.446 \mathrm{lton} /$ acre.

${ }^{\mathrm{y}}$ Small fruit $<65 \mathrm{~mm}$ diameter, medium fruit $=65$ to $75 \mathrm{~mm}$ diameter, large fruit $>75 \mathrm{~mm}$ diameter, $1 \mathrm{~mm}=0.0394$ inch.

xValues followed by the same letter in the same column are not significantly different at $P \leq 0.05$ level, according to Tukey's range test.

Ns, *Nonsignificant or significant at $P \leq 0.05$, respectively.

a plant biostimulant that encourages plant growth by increasing hormonal activity within plant tissues (Serenella et al., 2002). Both foliar or soil application of humic acid increased fruit fresh weight and total yield in 'Demre sivrisi' sweet pepper (Karakurt et al., 2009). Kazemi (2014) reported that fruit number per plant, fruit fresh weight, and total yield of tomato were improved by a foliar application of humic acid.

EFFECT OF HUMIC AND SALICYLIC ACIDS ON FRUIT PHYSICAL TRAITS. FOliar treatments with humic and salicylic acids significantly $(P \leq 0.05)$ increased fruit physical traits with a varied response from the three cultivars tested (Table 4). The fruit physical traits were significantly influenced by cultivars, foliar treatments, year, and the interaction for cultivars and foliar treatments. There was no significant influence for the interaction of year with cultivars on all physical traits except for fruit diameter. 'Ferrari' treated with $1.5 \mathrm{~g} \cdot \mathrm{L}^{-1}$ salicylic acid recorded the highest fruit length $(10.11 \mathrm{~cm})$, fruit diameter $(10.08 \mathrm{~cm})$, fruit thickness $(0.68$ $\mathrm{cm})$, fruit fresh weight $(202.41 \mathrm{~g})$, and fruit dry weight (14.06 g), as compared with the control, as well as with the other two cultivars. Significant differences in the length, width, and thickness of sweet pepper fruit have been reported for various cultivars grown under field conditions (Cebula et al., 2015; Jadczak et al., 2010). Buczkowska et al. (2014) described 'Caryca $F_{1}$ ' sweet pepper fruit as heavy fruit with a thick pericarp. Generally, pericarp thickness of sweet pepper fruit varies among different cultivars (Buczkowska et al., 2014). Both the fresh weight and flesh thickness of fruit are considered quality characteristics of sweet pepper that largely affect their appearance and consumer acceptance (Buczkowska et al., 2014; Jadczak et al., 2010). The differences in fruit weight are mainly attributed to variability among pepper cultivars. The average fruit fresh weight for 'Ferrari' (202.41 g) was similar to fruit weight reported by César de $\mathrm{O}$ Charlo et al. (2011) for 'Eppo $\mathrm{F}_{1}$ ' sweet pepper fruit $(200 \mathrm{~g})$, but higher than those reported by Krstic et al. (2013) for several sweet pepper cultivars $(39.22$ to $157.91 \mathrm{~g})$. In the present study, treatment with $1.5 \mathrm{~g} \cdot \mathrm{L}^{-1}$ of salicylic acid recorded the highest fruit dry weight, at 12.25, 14.06, and 12.41 g for 'Barbero', 'Ferrari', and 'Imperio', respectively. These dry weight values varied significantly among the three cultivars. Buczkowska et al. (2014) reported that dry weight of sweet pepper fruit is determined according to cultivar 
Table 4. Effect of humic and salicylic acid concentrations on the physical fruit traits of 'Barbero', 'Ferrari', and 'Imperio' sweet pepper.

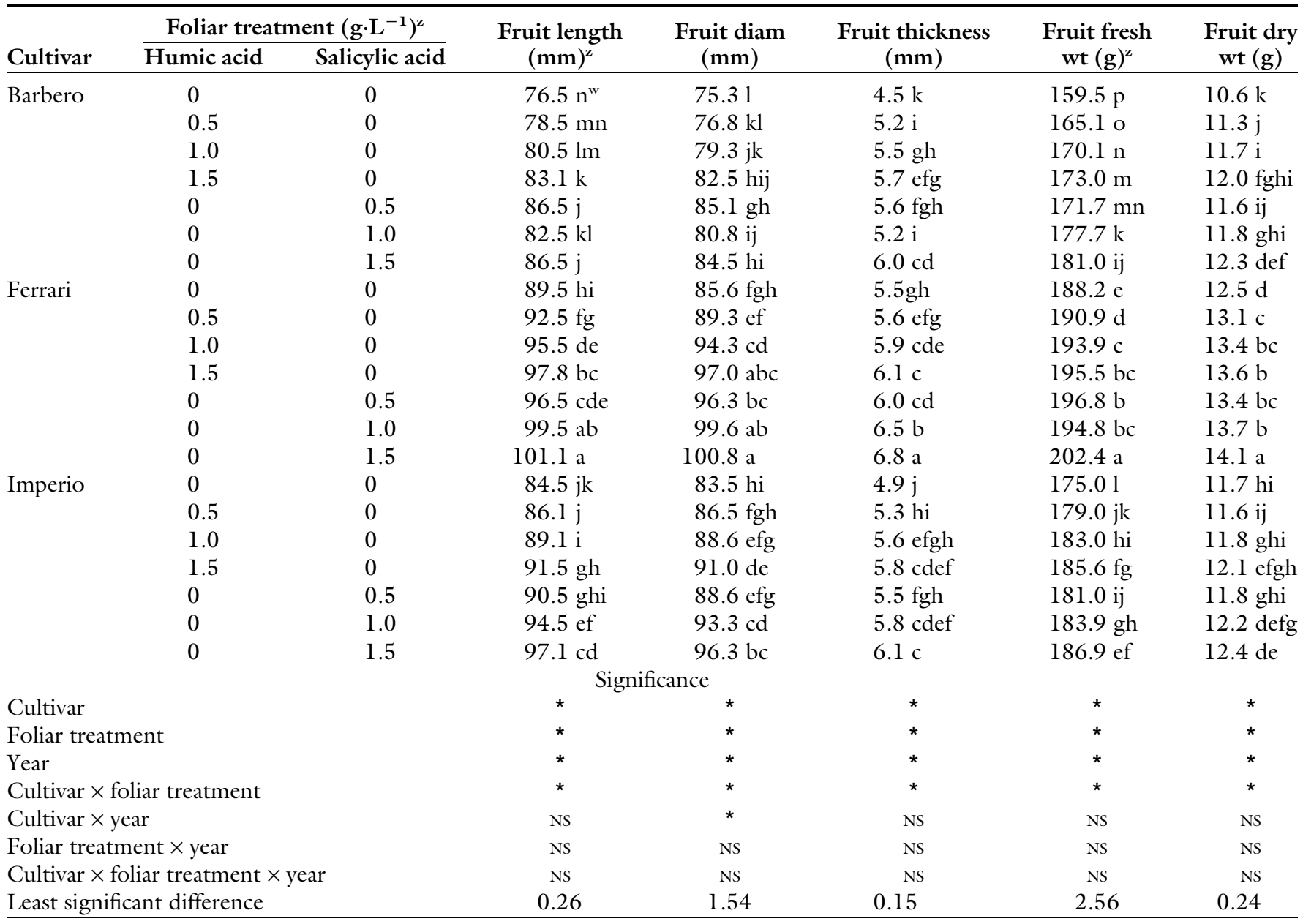

${ }^{\mathrm{z}} 1 \mathrm{~g} \cdot \mathrm{L}^{-1}=1000 \mathrm{ppm}, \mathrm{l} \mathrm{mm}=0.0394$ inch, $\mathrm{l} \mathrm{g}=0.0353 \mathrm{oz}$.

'Values followed by the same letter in the same column are not significantly different at $P \leq 0.05$ level, according to Tukey's range test.

Ns, *Nonsignificant or significant at $P \leq 0.05$, respectively.

characteristics. Our results indicate that the dry weight values for 'Barbero', 'Ferrari', and 'Imperio' were higher than those reported by Jadczak et al. (2010), who found that the fruit dry weight in 'ISI $56511 \mathrm{~F}_{1}$ ' and 'Roei $F_{1}$ ' sweet pepper plants were 7.36 and $10.29 \mathrm{~g}$, respectively. Humic acid treatment showed significant increase in physical fruit traits as compared with the control treatments for the three cultivars, but it was less effective than that observed in the salicylic acid treatment. Foliar application of $20 \mathrm{~mL} \cdot \mathrm{L}^{-1}$ humic acid significantly increased fruit weight, length, and diameter of 'Target NFl' tomato (Yildirim, 2007). However, Karakurt et al. (2009) reported that application of $20 \mathrm{~mL} \cdot \mathrm{L}^{-1}$ humic acid (foliar or soil drench) had no significant effect on the fruit length or diameter of 'Demre sivrisi' sweet pepper.
EFFeCt OF HUMic AND SALICYLIC ACIDS ON FRUIT NUTRITIONAL QUALITY TRAITs. Foliar application of humic and salicylic acids at the concentrations tested significantly $(P \leq 0.05)$ increased fruit nutritional quality traits of 'Barbero', 'Ferrari', and 'Imperio' red sweet pepper (Table $5)$. There was significant influence for cultivar, foliar treatments, year, and the interaction of foliar treatments with cultivars on all fruit nutritional quality traits. Salicylic acid at $1.5 \mathrm{~g} \cdot \mathrm{L}^{-1}$ recorded the highest values of vitamin $C$ at $200.8,200.8$, and $201.4 \mathrm{mg} / 100 \mathrm{~g}$ fresh weight for 'Barbero', 'Ferrari', and 'Imperio', respectively, as compared with those in the control treatment, at 178.8, 187.2 , and $181.2 \mathrm{mg} / 100 \mathrm{~g}$ fresh weight, for the three cultivars, respectively. Although the three cultivars showed increased content of vitamin $\mathrm{C}$, variability in titratable acidity and the percentages of total soluble solids and total sugars prevailed. At $1.5 \mathrm{~g} \cdot \mathrm{L}^{-1}$ salicylic acid, 'Barbero' recorded the highest percentage of titratable acidity $(0.39 \%)$ as compared with the controls $(0.32 \%)$, whereas 'Ferrari' and 'Imperio' recorded the highest total soluble solids $7.5 \%$ and $7.37 \%$, respectively) and total sugars $(7.18 \%$ and $7.05 \%$, respectively), when compared with the controls $6.63 \%$ and $6.40 \%$ soluble solids; $6.0 \%$ and $5.48 \%$ total sugars, respectively). In general, salicylic acid treatment resulted in higher values than humic acid treatment for all fruit quality traits (Table 4). Previous studies reported the improvement of fruit quality by salicylic acid treatment. Salicylic acid application at $0.4 \mathrm{~g} \cdot \mathrm{L}^{-1}$ resulted in increased total soluble solids, total sugars, and ascorbic acid in 'Yolo Wonder' sweet pepper fruit (Mahmood et al., 2017). Vitamin C, 
Table 5. Effect of humic and salicylic acid concentrations on fruit nutritional quality traits of 'Barbero', 'Ferrari', and 'Imperio' sweet pepper.

\begin{tabular}{|c|c|c|c|c|c|c|}
\hline \multirow{2}{*}{ Cultivar } & \multicolumn{2}{|c|}{ Foliar treatment $\left(\mathrm{g} \cdot \mathrm{L}^{-1}\right)^{\mathrm{z}}$} & \multirow{2}{*}{$\begin{array}{c}\text { Vitamin C } \\
(\mathrm{mg} / 100 \mathrm{~g} \mathrm{FW})^{\mathrm{z}}\end{array}$} & \multirow{2}{*}{$\begin{array}{r}\text { Titratable } \\
\text { acidity (\%) }\end{array}$} & \multirow{2}{*}{$\begin{array}{c}\text { Total soluble } \\
\text { solids (\%) }\end{array}$} & \multirow{2}{*}{$\begin{array}{c}\text { Total } \\
\text { sugars (\%) }\end{array}$} \\
\hline & Humic acid & Salicylic acid & & & & \\
\hline \multirow[t]{4}{*}{ Barbero } & 0 & 0 & $178.8 \mathrm{i}^{\mathrm{y}}$ & $0.318 \mathrm{~h}$ & $5.52 \mathrm{~h}$ & $4.83 \mathrm{i}$ \\
\hline & 1.0 & 0 & $191.3 \mathrm{ef}$ & $0.337 \mathrm{f}$ & $6.03 \mathrm{~g}$ & $5.65 \mathrm{gh}$ \\
\hline & 1.5 & 0 & $197.7 \mathrm{abc}$ & $0.361 \mathrm{de}$ & $6.50 \mathrm{ef}$ & $6.03 \mathrm{fg}$ \\
\hline & 0 & 0.5 & $192.4 \mathrm{def}$ & 0.348 ef & $6.12 \mathrm{~g}$ & $6.00 \mathrm{fg}$ \\
\hline \multirow[t]{5}{*}{ Ferrari } & 0 & 0 & $187.2 \mathrm{gh}$ & $0.342 \mathrm{f}$ & $6.63 \mathrm{def}$ & $6.00 \mathrm{fg}$ \\
\hline & 0.5 & 0 & $192.1 \mathrm{def}$ & $0.350 \mathrm{ef}$ & $6.77 \mathrm{cde}$ & $6.30 \mathrm{ef}$ \\
\hline & 1.0 & 0 & $196.6 \mathrm{bc}$ & $0.353 \mathrm{ef}$ & $6.90 \mathrm{bcd}$ & 6.60 bcde \\
\hline & 1.5 & 0 & $197.7 \mathrm{abc}$ & $0.369 \mathrm{c}$ & $7.07 \mathrm{bc}$ & $6.87 \mathrm{abc}$ \\
\hline & 0 & 0.5 & $194.5 \mathrm{cde}$ & $0.359 \mathrm{de}$ & $6.88 \mathrm{bcd}$ & $6.50 \mathrm{cde}$ \\
\hline & 1.0 & 0 & $190.3 \mathrm{fg}$ & $0.340 \mathrm{f}$ & $6.97 \mathrm{bc}$ & $6.63 \mathrm{bcde}$ \\
\hline & 1.5 & 0 & $195.4 \mathrm{bcd}$ & $0.350 \mathrm{ef}$ & $7.06 \mathrm{bc}$ & $6.82 \mathrm{abcd}$ \\
\hline & 0 & 0.5 & $191.4 \mathrm{ef}$ & $0.343 \mathrm{f}$ & $6.86 \mathrm{bcd}$ & $6.57 \mathrm{cde}$ \\
\hline & 0 & 1.0 & $198.7 \mathrm{ab}$ & $0.359 \mathrm{de}$ & $7.10 \mathrm{~b}$ & $6.83 \mathrm{abcd}$ \\
\hline & 0 & 1.5 & $\begin{array}{l}201.4 \text { a } \\
\text { Significance }\end{array}$ & $0.368 \mathrm{~cd}$ & $7.37 \mathrm{a}$ & $7.05 \mathrm{ab}$ \\
\hline \multicolumn{3}{|l|}{ Cultivar } & * & * & * & * \\
\hline \multicolumn{3}{|c|}{ Foliar treatment } & * & * & * & * \\
\hline \multicolumn{3}{|l|}{ Year } & * & * & * & * \\
\hline \multicolumn{3}{|c|}{ Cultivar $\times$ foliar treatment } & * & * & * & * \\
\hline \multicolumn{3}{|c|}{ Cultivar $\times$ year } & NS & NS & NS & NS \\
\hline
\end{tabular}

${ }^{\mathrm{z}} \mathrm{l} \mathrm{g} \cdot \mathrm{L}^{-1}=1000 \mathrm{ppm}, 1 \mathrm{mg} / 100 \mathrm{~g}=10 \mathrm{ppm}$.

y Values followed by the same letter in the same column are not significantly different at $P \leq 0.05$ level, according to Tukey's range test. Ns, *Nonsignificant or significant at $P \leq 0.05$, respectively.

total soluble solids, and titratable acidity were also increased in 'California Wonder' sweet pepper fruit in response to salicylic acid treatment at $0.1 \mathrm{~g} \cdot \mathrm{L}^{-1}$ (Abou El-Yazied, 2011). Application of salicylic acid (0.7 $\left.\mathrm{g} \cdot \mathrm{L}^{-1}\right)$ as a presowing seed treatment increased titratable acidity, but decreased total soluble solids in 'Cadia' sweet pepper (Hanieh et al., 2013). In the present study, fruit quality of sweet pepper was improved by applying salicylic acid at 1.0 to $1.5 \mathrm{~g} \cdot \mathrm{L}^{-1}$. Several studies reported that content of vitamin $\mathrm{C}$, titratable acidy, total soluble solids, and total sugars in sweet pepper fruit are cultivardependent and influenced by growth conditions (Alsadon et al., 2013; Buczkowska and Najda, 2002; Buczkowska et al., 2014; César de O Charlo et al., 2011; Deepa et al., 2006; Jamiołkowska et al., 2016; Koner et al., 2015).
Application of humic acid also improved fruit quality of 'Barbero', 'Ferrari', and 'Imperio' red sweet pepper when compared with the control group plants (Table 5). The content of vitamin $\mathrm{C}$ was the highest under the high humic acid concentration, in agreement with the observations of Giovanni et al. (2011), who reported that applying humic substances improved vitamin C content of tomato fruit. In addition, Aminifard et al. (2012) found that the vitamin $\mathrm{C}$ content of humic acid-treated hot pepper fruit was consistently elevated, although not significantly. In general, the level of vitamin $\mathrm{C}$ in vegetable crops depends on several factors, including cultivar type, plant nutrition, and maturity (Aminifard et al., 2012). Moreover, humic acid used in the present study included $12 \% \mathrm{~K}_{2} \mathrm{O}$, and the effect of $\mathrm{K}$ on sweet pepper fruit quality might be related to the nutritional quality (Flores et al., 2004; Rubio et al., 2010). The positive effect of humic acid on fruit quality also could be due to its indirect positive influence on the whole plant (Adani et al., 1998; Dursun et al., 2002; Fathima and Denesh, 2013). Our results confirm previous findings by Yildirim (2007) and Shahmaleki et al. (2014), who reported that application of humic acid $\left(20 \mathrm{~mL} \cdot \mathrm{L}^{-1}\right)$ as foliar spray or a drench to the plant root zone increased values of total soluble solids and vitamin $\mathrm{C}$ in fruit of 'Target NFl' tomato, when compared with the control.

\section{Conclusion}

Foliar application of humic or salicylic acids significantly increased growth, yield, and fruit nutritional quality of 'Barbero', 'Ferrari', and 'Imperio' sweet pepper. 'Ferrari' 
showed significantly higher yield and productivity than 'Barbero' or 'Imperio.' Salicylic acid (1.5 g. $\left.\mathrm{L}^{-1}\right)$ increased fruit weight, flesh thickness, and total yield by $15.9 \%$ to $27.7 \%$ depending on cultivar. In general, salicylic acid proved more effective than humic acid for the three cultivars tested. Therefore, we recommend the use of salicylic acid as foliar spray for enhancing the productivity and nutritional quality of red sweet pepper.

\section{Literature cited}

Adani, F., P. Genevi, P. Zaccheo, and G. Zocchi. 1998. The effect of commercial humic acid on tomato plant growth and mineral nutrition. J. Plant Nutr. 21:561575 .

Abou El-Yazied, A. 2011. Effect of foliar application of salicylic acid and chelated zinc on growth and productivity of sweet pepper (Capsicum annuum L.) under autumn planting. Res. J. Agr. Biol. Sci. $7: 423-433$.

Aghaeifard, F., M. Babalar, E. Fallahi, and A. Ahmadi. 2016. Influence of humic acid and salicylic acid on yield, fruit quality, and leaf mineral elements of strawberry (Fragaria $\times$ ananassa Duch.) cv. Camarosa. J. Plant Nutr. 39:1821-1829.

Alenazi, M., M.A. Wahb-Allah, H.S. Abdel-Razzak, A.A. Ibrahim, and A. Alsadon. 2016. Water regimes and humic acid application influences potato growth, yield, tuber quality and water use efficiency. Amer. J. Potato Res. 93:463-473.

Allen, R., L. Pereira, D. Raes, and M. Smith. 1998. Crop evapotranspiration guidelines for computing crop water requirements. FAO Irr. Drainage Paper 56. Food and Agriculture Organization of the United Nations, Rome.

Alsadon, A., M. Wahb-Allah, H. AbdelRazzak, and A. Ibrahim. 2013. Effects of pruning systems on growth, fruit yield and quality traits of three greenhousegrown bell pepper (Capsicum annuum L.) cultivars. Austral. J. Crop Sci. 7:13091316.

Aminifard, M.H., H. Aroiee, M. Azizi, H. Nemati, Z. Hawa, and E. Jaafar. 2012. Effect of humic acid on antioxidant activities and fruit quality of hot pepper (Capsicum annuum L.). J. Herbs Spices Med. Plants 18:360-369.

Association of Official Agricultural Chemists. 2000. Official methods of analysis. 12th ed. AOAC, Washington, DC.

Arimboor, R., R.B. Natarajan, K.R. Menon, L.P. Chandrasekhar, and V.
Moorkoth. 2015. Red pepper (Capsicum annuum L.) carotenoids as a source of natural food colors: Analysis and stability: A review. J. Food Sci. Technol. 52:12581271.

Asri, F.O., E.I. Demirtas, and N. Ari. 2015. Changes in fruit yield, quality and nutrient concentrations in response to soil humic acid applications in processing tomato. Bulg. J. Agric. Sci. 21:585-591.

Atiyeh, R.M., C.A. Edwards, J.D. Metzger, S. Lee, and N.Q. Arancon. 2002. The influence of humic acids derived from earthworm-processed organic wastes on plant growth. Bioresour. Technol. 84:7-14.

Barkosky, R.R. and F.A. Einhellig. 1993. Effects of salicylic acid on plant water relationship. J. Chem. Ecol. 19:237-247.

Brannon, C.A. and L.E. Sommers. 1985. Preparation and characterization of model humic polymers containing organic P. Soil Biol. Biochem. 17:213-219.

Buczkowska, H. and A. Najda. 2002. A comparison of some chemical compounds in the fruit of sweet and hot pepper (Capsicum annuum L.). Folia Hort. 14:59-67.

Buczkowska, H., A. Salata, and E. Rozek. 2014. Diversity of the utility and biological value of fruits of some sweet pepper cultivars. Acta Sci. Pol. Hortorum Cultus 13:49-62.

Bouyoucos, G.J. 1951. A recalibration of the hydrometer method for making mechanical analysis of soils. Agron. J. 43:435-438.

Cebula, S., A. Jakubas, A. Sękara, A. Kalisz, and A. Pohl. 2015. The relationship between morphological features and nutritive value of sweet pepper fruits. Acta Sci. Pol. Hortorum Cultus 14:79-91.

César de O Charlo, H., S.F. de Oliveira, R. Castoldi, P.F. Vargas, L.T. Braz, and J.C. Barbosa. 2011. Growth analysis of sweet pepper cultivated in coconut fiber in a greenhouse. Hort. Bras. 29:316-323.

Chapman, H.D. and P.F. Pratt. 1961. Methods of analysis for soils, plant and water. Univ. California, Div. Agr. Sci. Publ. 4034.

Chávez-Mendoza, C., E. Sanchez, E. Muñoz-Marquez, J.P. Sida-Arreola, and M.A. Flores-Cordova. 2015. Bioactive compounds and antioxidant activity in different grafted varieties of bell pepper. Antioxidants 4:427-446.

Dada, O.A. and Y.O. Ogunsesu. 2016. Growth analysis and fruit yield of Capsicum chinense, Jacquin as influenced by compost applied as foliar spray and soil augmentation in Ibadan, southwestern
Nigeria. J. Agr. Sustainability 9:83103.

Deepa, N., C. Kaura, B. Singhb, and H.C. Kapoor. 2006. Antioxidant activity in some red sweet pepper cultivars. J. Food Compos. Anal. 19:572-578.

Dursun, A., I. Guvenc, and M. Turan. 2002. Effects of different levels of humic acid on seedling growth and macro- and micro-nutrient contents of tomato and eggplant. Acta Agrobot. 56:81-88.

Elwan, M.W.M. and M.A.M. El-Hamahmy. 2009. Improved productivity and quality associated with salicylic acid application in greenhouse pepper. Scientia Hort. 122: 521-526.

Emmanuel-Ikpeme, C., P. Henry, and O.A. Okiri. 2014. Comparative evaluation of the nutritional, phytochemical and microbiological quality of three pepper varieties. J. Food Nutr. Sci. 2:74-80.

Eshghi, S. and M. Garazhian. 2015. Improving growth, yield and fruit quality of strawberry by foliar and soil drench applications of humic acid. Iran Agr. Res. 34:14-20.

Fathima, P.S. and G.R. Denesh. 2013. Influence of humic acid spray on growth and yield of chili (Capsicum annumm L.). Intl. J. Agr. Sci. 9:542-546.

Flores, P., J.M. Navarro, C. Garrido, J.S. Rubio, and V. Martinez. 2004. Influence of $\mathrm{Ca}^{2+}, \mathrm{K}^{+}$and $\mathrm{NO}_{3}{ }^{-}$fertilization on nutritional quality of pepper. J. Sci. Food Agr. 84:569-574.

Ghabbour, E.A. and G. Davies. 2001. Humic substances: Structures, models and functions. Royal Soc. Chem., Cambridge, UK.

Giovanni, M., G.L. Angela, and L.M. Antonino. 2011. The effect of organic supplementation of solarized soil on the quality of tomato fruit. Scientia Hort. 129:189-196.

Gunes, A., A. Inal, M. Alpaslan, N. Cicek, E. Guneri, F. Eraslan, and T. Guzelordu. 2005. Effects of exogenously applied salicylic acid on the induction of multiple stress tolerance and mineral nutrition in maize (Zea mays L.). Arch. Agron. Soil Sci. 51:687-695.

Hanafy Ahmed, A.H., M.R. Nesiem, A.M. Hewedy, and H. El-S. Sallam. 2010. Effect of some simulative compounds on growth, yield and chemical composition of snap bean plants grown under calcareous soil conditions. J. Amer. Sci. 6:552569.

Hanieh, A., D. Mojtaba, Z. Zabihollah, and A. Vahid. 2013. Effect of pre-sowing salicylic acid seed treatment on seed germination and growth of greenhouse sweet 
pepper plants. Indian J. Sci. Technol. 6:3868-3871.

Harmanto, V., M. Salokhea, M. Babelb, and $\mathrm{H}$. Tantau. 2005. Water requirement of drip irrigated tomatoes grown in greenhouse in tropical environment. Agr. Water Mgt. 71:225-242.

Haytova, D. 2013. A review of foliar fertilization of some vegetables crops. Annu. Rev. Res. Biol. 3:455-465.

Jadczak, D., M. Grzeszczuk, and M. Kosecka. 2010. Quality characteristics and content of mineral compounds in fruit of some cultivars of sweet pepper (Capsicum annuum L.). J. Elementol. 15:509-515.

Jamiołkowska, A., H. Buczkowska, and A.H. Thanoon. 2016. Effect of biological preparations on content of saccharides in sweet pepper fruits. Acta Sci. Pol. Hortorum Cultus 15:65-75.

Jayakannan, M., J. Bose, O. Babourina, Z. Rengel, and S. Shabala. 2015. Salicylic acid in plant salinity stress signaling and tolerance. Plant Growth Regulat. 76:2540 .

Jovicich, E., D.J. Cantliffe, P.J. Stoffella, and D.Z. Haman. 2007. Bell pepper fruit yield and quality as influenced by solar radiation-based irrigation and container media in a passively ventilated greenhouse. HortScience 42:642-652.

Karakurt, Y., H. Unlu, H. Unlu, and H. Padem. 2009. The influence of foliar and soil fertilization of humic acid on yield and quality of pepper. Acta Agriculturae Scandinavica Section B Soil Plant Sci. 59:233-237.

Kazemi, M. 2014. Effect of foliar application of humic acid and calcium chloride on tomato growth. Bul. Environ. Pharmacol. Life Sci. 3:41-46.

Khan, W., B. Prithiviraj, and D.L. Smith. 2003. Photosynthetic responses of corn and soybean to foliar application of salicylates. J. Plant Physiol. 160:485-492.
Khan, M.I., M. Fatma, T.S. Per, N.A. Anjum, and N.A. Khan. 2015. Salicylic acid-induced abiotic stress tolerance and underlying mechanisms in plants. Front. Plant Sci. 6:1-17.

Koner, S., R. Chatterjee, and S. Datta. 2015. Effect of planting dates and varieties on growth, fruit yield and quality of bell pepper (Capsicum annuum L.). J. Appl. Nat. Sci. 7:734-738.

Krstic, B., A. Tepic, N. Nikolic, Dj. Gvozdenovic, and M. Tomicic. 2013. Chemical variability of inedible fruit parts in pepper varieties (Capsicum annuиm L.). Bulg. J. Agr. Sci. 19:490-496.

Mahmood, N., N.A. Abbasi, I. Hafiz, I. Ali, and S. Zakia. 2017. Effect of biostimulants on growth, yield and quality of bell pepper cv. Yolo Wonder. Pakistan J. Agr. Sci. 54:311-317.

Manas, D., P.K. Bandopadhyay, A. Chakravarty, S. Pal, and A. Bhattacharya. 2014. Effect of foliar application of humic acid, zinc and boron on biochemical changes related to productivity of pungent pepper (Capsicum annuиm L.). Afr. J. Plant Sci. 8:320-335.

Maynard, D.N. and G.J. Hochmuth. 2007. Knott's handbook for vegetable growers. Wiley, Hoboken, NJ.

Paradikovic, N., T. Vinkovic, I. VinkovicVrcek, I. Zuntar, M. Bojic, and M. MedicSaric. 2011. Effect of natural biostimulants on yield and nutritional quality: An example of sweet yellow pepper (Capsicum annumm L.) plants. J. Sci. Food Agr. 91:2146-2152.

Pérez-Jiménez, M., M. Pazos-Navarrob, J. López-Marina, A. Galvez, P. Varóc, and F.M. del Amora. 2015. Foliar application of plant growth regulators changes the nutrient composition of sweet pepper (Capsicum annumm L.). Scientia Hort. 194:188-193.

Rivas-San Vicente, M. and J. Plasencia. 2011. Salicylic acid beyond defense: Its role in plant growth and development. J. Expt. Bot. 62:3321-3338.
Rubio, J.S., F. García-Sánchez, P. Flores, J.M. Navarro, and V. Martínez. 2010. Yield and fruit quality of sweet pepper in response to fertilization with $\mathrm{Ca}^{2+}$ and $\mathrm{K}^{+}$. Span. J. Agr. Res. 8:170-177.

Sahu, G.K. 2013. Salicylic acid: Role in plant physiology and stress tolerance, $\mathrm{p}$. 217-239. In: G.R. Rout and A.B. Das (eds.). Molecular stress physiology of plants. Springer India, Bhubaneswar, India.

Salman, S.R., S.D. Abou-hussein, A.R. Abdel-Mawgoud, and M.A. El-Nemr. 2005. Fruit yield and quality of watermelon as affected by hybrids and humic acid application. J. Appl. Sci. Res. 1:5158.

Serenella, N., D. Pizzeghelloa, N. Muscolob, and A. Vianello. 2002. Physiological effects of humic substances on higher plants. Soil Biol. Biochem. 34:15271536.

Shahmaleki, S.K., G.A. Peyvast, and M. Ghasemnezhad. 2014. Acid humic foliar application affects fruit quality characteristics of tomato (Lycopersicon esculentum cv. Izabella). Agr. Sci. Dev. 3:312-316.

Souri, M.K., F.Y. Sooraki, and M. Moghadamyar. 2017. Growth and quality of cucumber, tomato, and green bean under foliar and soil applications of an aminochelate fertilizer. Hort. Environ. Biotechnol. 58:530-536.

The Plant List. 2019. Capsicum. 16 Jan. 2019. <http://www.theplantlist.org/ browse/A/Solanaceae/Capsicum/>.

Unlu, H.O., H. Unlu, Y. Karakurt, and H. Padem. 2011. Changes in fruit yield and quality in response to foliar and soil humic acid application in cucumber. Sci. Res. Essays 6:2800-2803.

Yildirim, E. 2007. Foliar and soil fertilization of humic acid affect productivity and quality of tomato. Acta Agriculturae Scandinavica Section B Soil Plant Sci. 57:182-186. 